\title{
The Pivotal Role of Integrin $\beta 1$ in Metastasis of Head and Neck Squamous Cell Carcinoma
}

\author{
Dongsheng Wang ${ }^{1}$, Susan Müller ${ }^{2}$, A.R.M. Ruhul Amin ${ }^{1}$, Donghai Huang ${ }^{1}$, Ling Su ${ }^{1}$, \\ Zhongliang Hu${ }^{1}$, Mohammad Aminur Rahman ${ }^{1}$, Sreenivas Nannapaneni ${ }^{1}$, Lydia Koenig ${ }^{1}$, \\ Zhengjia Chen ${ }^{3}$, Mourad Tighiouart ${ }^{3}$, Dong M. Shin ${ }^{1}$, and Zhuo G. Chen ${ }^{1, *}$ \\ ${ }^{1}$ Department of Hematology and Medical Oncology, Winship Cancer Institute, Emory University \\ School of Medicine, Atlanta, GA \\ ${ }^{2}$ Department of Pathology and Laboratory Medicine, Emory University School of Medicine, \\ Atlanta, GA \\ ${ }^{3}$ Department of Biostatistics and Bioinformatics, Emory University School of Medicine, Atlanta, \\ $\mathrm{GA}$
}

\begin{abstract}
Purpose - This study aimed to understand the prognostic value of integrin $\beta 1$ expression in head and neck squamous cell carcinoma (HNSCC) and the mechanism underlying its association with metastatic HNSCC.
\end{abstract}

Experimental Design-Archival HNSCC tissues including 99 non-metastatic primary tumors and 101 metastatic primary tumors were examined for the association of integrin $\beta 1$ expression with metastasis and disease prognosis by appropriate statistical methods. Fluorescence activated cell sorting was used to separate the integrin $\beta 1^{\mathrm{high} /+}$ cell population from the integrin $\beta 1^{\text {low/- }}$ population in HNSCC cell lines. These two populations and integrin $\beta 1$ shRNA knock-down HNSCC cells were examined for the effect of integrin $\beta 1$ on invasion in vitro and on lymph node and lung metastases in a xenograft mouse model. Expression and activation of matrix metalloproteinases (MMPs) were examined by zymography.

\begin{abstract}
Results-Statistical analysis showed that integrin $\beta 1$ expression was significantly higher in the metastatic primary tumors than in the non-metastatic tumors ( $42.6 \%$ vs $24.8 \%, \mathrm{p}<0.0001$ and $\mathrm{p}<0.0001$ by univariate and multivariate analyses, respectively). In patients with lymph node metastasis, integrin $\beta 1$ expression was inversely correlated with overall survival $(\mathrm{p}=0.035)$. The integrin $\beta 1$ knock-down or integrin $\beta 1^{\text {low/- }}$ HNSCC cells showed a significant reduction in lymph node and lung metastases in vivo ( $<<0.001$ and $\mathrm{p}<0.05$, respectively). Significantly reduced matrigel invasion capability was also found in integrin $\beta 1$ knock-down or integrin $\beta 1^{\text {low/- }}$ HNSCC cells $(p<0.01)$. Finally, zymography results showed integrin $\beta 1$ affected HNSCC invasion by regulating MMP-2 activation.
\end{abstract}

Conclusion-These findings indicate that integrin $\beta 1$ has a major impact on HNSCC prognosis through its regulation of metastasis.

\footnotetext{
"Corresponding Author: Zhuo (Georgia) Chen, Department of Hematology and Medical Oncology, Winship Cancer Institute, Emory University School of Medicine, 1365-C Clifton Road, Suite C3086, Atlanta, GA 30322. Phone: 404-778-3977; Fax: 404-778-5520; gzchen@emory.edu.
}

Disclosure of Potential Conflicts of Interest

No potential conflicts of interest to disclose 


\section{Introduction}

Head and neck cancer (HNC) is one of the most common cancers and is responsible for almost 200,000 deaths around the world every year $(1,2)$. HNC accounted for an estimated 49,260 new cases and 11,480 deaths in the US alone in 2010 (3). Squamous cell carcinoma (SCC) represents $90 \%$ of $\mathrm{HNC}$ cases and is a highly heterogeneous disease. Both locoregional recurrences and lymph node metastasis (LNM) of HNSCC are associated with a poor prognosis. Despite the advances in understanding of the biological behavior of HNC, along with its improved diagnosis, the 5-year survival rate has been virtually unchanged in the past 30 years, remaining at 54\% for patients with regional LNM and $32 \%$ for patients with distant metastasis $(1,3)$. Therefore, better understanding of the molecular mechanisms underlying the metastasis of HNC will contribute significantly to predicting and guiding the treatment of this disease.

The mechanisms underlying metastasis in most cancers are still poorly understood (4). Like other cancers, HNC metastasis is a multistep process that results from the accumulation of multiple genetic and epigenetic alterations (5-7). It has been shown that carcinoma cells first invade the surrounding stroma, then migrate and intravasate into the blood or lymphatic vessels and survive anoikis. Once arrested in the capillaries of a distant location or organ, they will penetrate the adjacent parenchyma, and adapt to the newly colonized milieu or subvert the local microenvironment to form the new tumor. Many genes and proteins take part in these multiple steps that facilitate the metastatic process, one of which is integrin $\beta 1$. Integrins are a family of transmembrane glycoproteins. Their non-covalently linked $\alpha$ and $\beta$ subunits together support and modulate various cellular functions that are required for cancer survival and metastasis $(8,9)$. Integrin $\beta 1$ drew our attention because its expression was found to be much higher in highly metastatic HNSCC cells selected in vivo than in their poorly metastatic counterpart $(10,11)$. The role of integrin $\beta 1$ in the metastasis of several types of cancer has been studied $(8,12)$. Integrin $\beta 1$ expression in HNSCC has been reported by several researchers. Van Waes et al showed that integrin $\beta 1$ expression was increased in tissue specimens from 80 patients with SCC of the upper aerodigestive tract and in cell lines derived from neoplasms. Their results suggested that an increase in suprabasilar expression of integrin $\beta 1$ may be advantageous for tumor progression (13). Koivisto et al showed that integrins $\alpha 1 \beta 1$, av $\beta 1$, and av $\beta 6$ collaborated in supporting SCC cell spreading and migration on fibronectin (14). However, the contribution of integrin $\beta 1$ to HNSCC metastasis and prognosis remains to be demonstrated. Matrix metalloproteinases (MMPs) are enzymes that degrade components of the extracellular matrix (ECM) and thus play a pivotal role in cell migration and ECM remodeling during physiological and pathological processes $(15,16)$. Although integrin $\beta 1$ has been widely studied, its interaction with MMPs has not been fully defined (17).

In this study, we address the roles of integrin $\beta 1$ in the metastasis of HNSCC on three fronts: HNSCC cell lines, a xenograft animal model, and tissue specimens obtained from patients with HNSCC. Firstly, we analyzed the integrin $\beta 1$ expression level in tissue specimens obtained from 200 patients with HNSCC (101 from patients with lymph node metastasis and 99 from patients without lymph node metastasis) and determined the correlation between its expression and metastasis. Next, we differentiated integrin $\beta 1^{\text {high/+ }}$ from integrin $\beta 1^{\text {low/- }}$ cells and knocked down integrin $\beta 1$ with shRNA in HNSCC cells. The incidence of metastases between knock-down cells and control cells and between integrin $\beta 1^{\text {high/+ }}$ and integrin $\beta 1^{\text {low/- }}$ cells was compared in a xenograft mouse model. These cells were further used to investigate the effect of integrin $\beta 1$ on cancer cell invasion and MMP activities. 


\section{Materials and Methods}

\section{Human tissue specimens and cell lines}

Using an institutional review board-approved consent for tissue acquisition, clinical samples for this study were obtained from surgical specimens from patients diagnosed with HNSCC from 1994 to 2003 at Emory University Hospital, whose initial treatment was surgery and who had never received prior treatment with radiation and/or chemotherapy. The selection criteria applied to the available formalin-fixed and paraffin-embedded tissue blocks included 2 groups: primary SCC with positive lymph nodes (N-positive) (101 patients; the $\mathrm{Tu}^{+\mathrm{Met}}$ group) and primary SCC with negative lymph nodes ( $\mathrm{N}$-negative) (99 patients; the $\mathrm{Tu}^{-\mathrm{Met}}$ group). In the $\mathrm{Tu}^{-\mathrm{Met}}$ group, none of the patients developed metastases within 2 years of the initial procedure. In addition, 10 benign oral soft tissue specimens from non-cancer patients were used as normal controls. The clinical information on the samples was obtained from the surgical pathology files in the Department of Pathology at Emory University according to the regulations of the Health Insurance Portability and Accountability Act. The clinicopathologic parameters for the 2 study groups, including age, sex, tobacco history, tumor location, and disease stage, are characterized and listed in Supplementary data Table S1. Each patient's disease free survival (DFS) and overall survival (OS) were documented through June, 2011. The HNSCC cell lines M4E, 212LN, and PCI-37B were maintained as a monolayer culture in Dulbecco's modified Eagle's medium (DMEM)/F12 medium (1:1) supplemented with $10 \%$ fetal bovine serum (FBS) as previously described $(11,18)$. Their human originality was confirmed by genotyping (data not shown).

\section{Immunohistochemistry (IHC) staining}

Formalin-fixed, paraffin-embedded tissue sections were used for immunohistochemistry (IHC), as described previously (19). The slides were incubated with anti-integrin $\beta 1$ primary antibody (BD Bioscience, San Jose, CA), anti-MMP 2 antibody (Abcam, Cambridge, MA), anti MT1-MMP antibody (Millipore,Temcula CA), and anti MMP 9 antibody (Santa Cruz Biotechnology Inc, Santa Cruz,CA). The staining of the antibody was observed by diaminobenzidine tetrahydrochloride peroxidase substrate solution (Vector Laboratories, Burlingame, CA). Cell nuclei were counterstained by using Hematoxylin QS (Vector Laboratories). Mouse immunoglobulin $\mathrm{G}(\mathrm{IgG})$ was used as a negative control, and normal epithelial tissue with known positive immunoreactivity to integrin $\beta 1$ was used as a positive control. The intensity of IHC staining was quantified and represented by the percentage of positive stained cells among all cancer cells. The percentage was determined by 2 individuals, and the final values were the average of the 2 readings.

\section{Fluorescence activated cell sorting (FACS)}

Monolayer-growing cells were trypsinized and washed with phosphate-buffered saline (PBS). Cells $\left(1 \times 10^{6}\right)$ were resuspended in $90 \mu \mathrm{PBS} / 1 \%$ BSA buffer and mixed with $10 \mu \mathrm{l}$ PE-mouse anti-human integrin $\beta 1$ antibody (BD Bioscience, San Diego, CA). Isotype control was carried out by adding $10 \mu \mathrm{l}$ PE-mouse IgG2a $\kappa$ instead of the specific antibody. The cell samples were incubated at $4^{\circ} \mathrm{C}$ for 1 hour and then washed with $1 \mathrm{ml}$ PBS/1\%BSA buffer 3 times. Finally the cells were resuspended and analyzed by FACS (BD Bioscience).

\section{Stable transfection of integrin $\beta 1$ shRNA}

To knock down integrin $\beta 1$ in M4E and PCI37B cells, we used pLVTHM vector (Addgene). On-line software from www.ambion.com was used to locate 3 potential siRNA sequences. Three pairs of shRNA were designed following the protocol provided by lentiweb.com. Basically, 3 pairs of oligonucleotides each containing the shRNA sequence and hairpin sequence plus Mlu1 and Cla1 sites were synthesized and cloned into the pLVTHM lentiviral 
vector, which contains a green fluorescent protein (GFP) insert. Only one of the three constructed targeting sequences 'ggaatgcctacttctgcac' showed a significant knock-down effect. Cells transfected with pLVTHM/shRNA were then purified using FACS based on their GFP expression. Western blot was carried out to confirm the integrin $\beta 1$ knock-down efficiency in these purified cells. Integrin $\beta 1$ knock-down cells were named PCI-37B-15 and M4E-15 cells.

\section{Metastatic xenograft mouse model}

Animal experiments were approved by the Animal Care and Use Committee of Emory University. Nineteen nude mice (athymic nu/nu, Taconic, NY, USA) aged 4-6 weeks (about $20 \mathrm{~g}$ body weight) were randomly divided into two groups. M4E cells suspended in $0.10 \mathrm{ml}$ of Hanks-buffered saline were orthotopically injected into the submandibular to mylohyoid muscle as described previously (11). Each animal in group 1 was injected with $1 \times 10^{6}$ M4E/pLVTHM control cells. Animals in group 2 were injected with $1 \times 10^{6}$ M4E-15 cells. The xenograft tumors were measured three times per week. Mice were euthanized 4 weeks after the initial injection, and cervical lymph nodes and lungs were collected, fixed immediately in $10 \%$ buffered formalin, and embedded in paraffin. Tissue sections were stained with hematoxylin-eosin. Lymph node and lung metastases were identified by two pathologists (SM and YW).

\section{Western blot analysis}

Cells were washed twice with PBS before being lysed on ice for 30min with lysis buffer containing 50mmol/L HEPES buffer, $150 \mathrm{mmol} / \mathrm{L} \mathrm{NaCl}, 1 \mathrm{mmol} / \mathrm{L}$ EDTA $(\mathrm{pH} 8.0), 1 \mathrm{mmol} /$ L EGTA(pH8.0), 1\% IGEPAL CA-630, 0.5\% Triton X-100, 10mmol/L NaF, $2 \mathrm{mmol} / \mathrm{L}$ $\mathrm{Na}_{3} \mathrm{VO}_{4}, 10 \mathrm{mmol} / \mathrm{L} \beta$-glycerophosphate and $1 \%$ Protease Inhibitor Cocktail (SigmaAldrich, St Louis, MO). The lysate was centrifuged at $16,000 \mathrm{~g}$ at $4^{\circ} \mathrm{C}$ for $15 \mathrm{~min} .50$ micrograms of total protein for each sample were separated by 10\% SDS-PAGE and transferred onto a Westran S membrane (Whatman Inc. Floham Park, NJ), and desired proteins were probed with corresponding antibodies. Mouse anti-integrin $\beta 1$ (1:100 dilution) was purchased from BD Bioscience, mouse anti-human actin (1:100 dilution) from Sigma (St. Louis, MO), anti-MMP 2 antibody from Abcam (Cambridge, MA) and anti MT1-MMP antibody from Millipore (Temcula CA). HRP-conjugated secondary anti-mouse IgG $(\mathrm{H}+\mathrm{L})$ was obtained from Promega, Madison, WI. Bound antibody was detected using the SuperSignal West Pico Chemoluminescence system (Pierce, Inc., Rockford, IL).

\section{Matrigel invasion assay}

The matrigel invasion assay was performed using the matrigel basement membrane matrix according to the manufacturer's protocol (Becton Dickinson Biosciences Discovery Labware, Bedford, MA). Briefly, $3 \times 10^{4}$ cells in $0.5 \mathrm{~mL}$ of serum-free medium were seeded in the invasion chamber containing the matrigel membrane (27.2 $\mathrm{ng}$ per chamber) in triplicate and allowed to settle for 3 hours at $37{ }^{\circ} \mathrm{C}$. NIH3T3-conditioned medium was added as a chemoattractant in the lower compartment of the invasion chamber. The chambers were incubated for 36 hours at $37{ }^{\circ} \mathrm{C}$ in a $5 \% \mathrm{CO}_{2}$ atmosphere. The invading cells appeared at the lower surface of the membrane. The upper surface of the membrane was scrubbed with a cotton swab and the absence of cells in the upper surface was confirmed under the light microscope. After the cells were fixed and stained with crystal violet, the membrane was placed on a microscope slide with the bottom side up and covered with immersion oil and a cover slip. Cells were counted under a microscope as a sum of 10 high power fields that were distributed randomly on the central membrane. The experiment was repeated 3 times. 


\section{Gelatin zymography}

M4E and PCI37B cells and their integrin $\beta 1$ knock-down counterparts M4E-15 and 37B-15 were seeded at the same numbers on 10 -cm petri-dishes. Cells were serum deprived once they reached $70 \%$ confluence. After 24 hours, the medium was collected and centrifuged at $12000 \mathrm{rpm}$ at $4{ }^{\circ} \mathrm{C}$. The medium sample was mixed with $3 \times$ SDS loading buffer, and a $30 \mu \mathrm{l}$ sample was loaded for each cell line. After gel electrophoresis, the gel was incubated in buffer A (10mM Tris-HCl, 2.5\% Triton X-100, $\mathrm{pH}=7.4)$ with gentle agitation twice for 30 minutes at room temperature. Buffer A was decanted and replaced with buffer B $(50 \mathrm{mM}$ Tris- $\mathrm{HCl} 10 \mathrm{mM} \mathrm{CaCl}_{2}$ ) at $37^{\circ} \mathrm{C}$ overnight for maximum sensitivity. The gel was stained with Coomassie Blue R for 30 mins, then destained with an appropriate Coomassie R-250 destaining solution (methanol: acetic acid: water [50: 10: 40]). Areas of protease activity appeared as clear bands against a dark blue background where the protease has digested the substrate. Activated MMP-2 abundance was quantified using UVP BioImaging System, (Upland, CA) to measure the density of specific bands.

\section{Statistical analyses}

The patients' characteristics were summarized and compared between patients with metastatic and nonmetastatic tumors. Age was presented as a median (range) and compared using Wilcoxon's rank sum test. Other variables, such as sex, smoking, site, T, N, stage, chemotherapy, radiation, differentiation level (MD: moderately differentiated, PD: poorly differentiated, WD: well differentiated) were treated as categorical variables and compared with Chi-square test.

For univariate analysis, since the sample size was relatively large and the residuals from the methods satisfied the normality and homoscedasticity assumptions, integrin $\beta 1$ expression was treated as a continuous outcome. Analysis of variance (ANOVA) was employed to test the overall significance across different strata of each independent variable. We further evaluated pairwise differences by using Tukey's method when the overall difference was significant at the significance level of 0.05 . For multivariate analysis, a general linear model (GLM) approach was used to estimate the adjusted relationship between integrin $\beta 1$ and each independent variable after adjustment for all other factors. Age was treated as continuous variable and all other factors were treated as categorical variables.

Time of OS was calculated as the time from study enrollment to death or last contact. Time of DFS was calculated as the time from study enrollment to the date of disease progression, death, or last contact, whichever was earliest. DFS and OS were estimated by the method of Kaplan and Meier (20). The log rank test was used to determine the difference in the overall DFS or OS between different groups stratified by the factors. A COX model (21) was also employed to estimate the adjusted effect of integrin $\beta 1$ on DFS or OS after adjustment for other factors as well as the adjusted effects of other factors on DFS or OS. Both point and 95\% confidence interval (CI) estimates of DFS and OS survival probabilities at different time points (e.g., 1, 3, or 5 years after study enrollment, etc.) were calculated. The SAS statistical package (SAS Institute, Inc., Cary, North Carolina) was used for all data management and analyses.

\section{Results}

\section{Prognostic significance and metastatic correlation of integrin $\beta 1$ in HNSCC}

The characteristics of all patients are summarized in supplemental data Table S1. Integrin $\beta 1$ showed a membranous and cytoplasmic expression pattern by IHC analysis in these patient tissues (Fig 1). The results of univariate analysis of integrin $\beta 1$ expression in primary tumors are summarized in Table 1A. Integrin $\beta 1$ expression in the primary tumor was found to be 
significantly higher in patients with metastatic tumors than in those with non-metastatic tumors ( $42.6 \%$ vs $24.8 \%, p<0.0001$ ), but there was no significant difference in integrin $\beta 1$ expression between the primary tumor in patients with metastatic tumors and lymph node metastasis $(42.6 \%$ vs $41.5 \%, \mathrm{p}=0.82)$. Integrin $\beta 1$ expression level in the primary tumor was $33.6 \%$ in patients with stage I, $19.2 \%$ in stage II, $24.5 \%$ in stage III and $41.1 \%$ in patients with stage IV disease $(\mathrm{p}=0.0001)$. However, integrin $\beta 1$ expression in the primary tumor was not significantly associated with age, sex, site, $\mathrm{T}$ stage, post-surgery radiation therapy, chemotherapy, smoking, or differentiation at a significance level of 0.05 (Table 1A). We further divided both metastatic and non-metastatic patients into 4 groups, respectively by grading scale $(0 \sim 25,26 \sim 50,51 \sim 75,76 \sim 100 \%)$ to understand the pattern of integrin $\beta 1$ expression. A significant difference in integrin $\beta 1$ expression level in the primary tumor was observed ( $<<0.0001$ by Chi-Square analysis) (Table 1B and Fig 1). More patients with metastasis had higher integrin $\beta 1$ level than patients without metastasis. For example, $21 \%$ of patients with metastasis had an integrin $\beta 1$ expression level of $76-100 \%$, compared with only $1 \%$ of patients without metastasis.

The multivariate analysis of integrin $\beta 1$ expression in the primary tumor is summarized in Table 2 . Integrin $\beta 1$ in the primary tumor was still significantly associated with metastasis status $(\mathrm{p}<0.0001)$ and primary tumor site $(\mathrm{p}<0.0044)$ after additional adjustment for age, sex, disease site, disease differentiation, and smoking. Although the tumor site was not correlated with integrin $\beta 1$ expression (Table 1A), it was found to be a significant factor after adjusting for confounding effect of disease status (metastasis $v s$ non-metastasis, Table 2 and Table S1). Integrin $\beta 1$ expression in the primary tumor, treated as a continuous variable, was not significantly associated with DFS or OS after fully adjusting for age, sex, disease site, disease differentiation, and smoking (supplemental data Table S2 A and B) for all patients using a COX model. However the same analysis showed integrin $\beta 1$ expression level was inversely related to OS among patients with metastasis $(\mathrm{p}=0.0352)$ (supplemental data Table S2 C).

Our data also showed that differences in the tumor $(\mathrm{T})$ stage were marginally significant between patients with and without metastasis $(\mathrm{p}<0.04)$. Among patients with metastatic tumors, more patients presented with stage IV $(83 \%)$ or stage III (17\%) disease. In contrast, patients with non-metastatic tumors typically had lower disease stages: stage I (43\%) and stage II (31\%), versus stage III (12\%) and stage IV (14\%). The tumor site was found to correlate with metastasis: oral cavity (OC: 39\%) > oropharynx (OP: 33\%) > larynx (L: 28\%) $(\mathrm{p}<0.0001)$. Significantly more patients with metastatic tumors had moderately differentiated (MD) tumors and significantly fewer had well differentiated (WD) tumors, compared with patients with non-metastatic tumors $(\mathrm{p}<0.0001)$ (supplemental data Table S1). Patients with non-metastatic tumors had significantly better DFS and OS than those with metastatic tumors (supplemental data, Fig S1 A and B). Metastasis status was a significant predicator of DFS or OS after adjustment for age, integrin $\beta 1$, sex, disease site, disease differentiation, and smoking (supplemental data, Table S2 A and B). As illustrated in our supplemental data (Table S1), 18\% (18 out of 101) of patients with metastasis and 5\% (5 out of 99) of patients without metastasis had chemotherapy. 87\% (87 out of 101) of patients with metastasis and 36\% (36 out of 99) of patients without metastasis were treated with radiation therapy. Patients who received chemotherapy had worse DFS and OS than patients who did not receive chemotherapy (supplemental data Fig S2 A and B). This result is not surprising since comprehensive treatment is usually reserved for late stage patients. There was no effect of radiation therapy on DFS and OS (data not shown). 


\section{Differential capabilities in invasion and metastasis between integrin $\beta 1^{\text {high/+ }}$ and integrin $\beta 1^{\text {low/- }}$ cancer cells}

To explore whether HNSCC populations with different integrin $\beta 1$ expression levels have different invasion abilities, we separated M4E and 212LN cells using a specific anti-integrin $\beta 1$ antibody. Integrin $\beta 1$-positive (or high) and -negative (or low) cells were isolated by FACS. Isolated M4E and 212LN cells were seeded in the number of $3 \times 10^{4}$ per chamber, and a matrigel invasion assay was performed. The number of invasive cells was counted as a sum of 10 high-power fields $(\times 200)$ in the central membrane under the microscope. Fig 2 shows the relative number of invasive cells from both M4E (Fig 2A) and 212LN (Fig 2B) cell lines. Analysis of invasive cells from each cell line was repeated 3 times. Integrin $\beta 1$ positive populations in both 212LN and M4E cells showed significantly higher invasive abilities in matrigel than their negative counterparts. As shown in Fig $2 \mathrm{C}$, there were greater numbers of invasive integrin $\beta 1^{+} \mathrm{M} 4 \mathrm{E}$ cells in the lower part of the chamber membrane than integrin $\beta 1^{-}$M4E cells.

We then orthotopically injected M4E integrin $\beta 1$-positive and-negative cells into nude mice. Mice were sacrificed after 4 weeks. Lymph nodes of all the mice were collected and subjected to H\&E staining. All 5 of the mice injected with integrin $\beta 1^{\text {high/+ }}$ cells developed LNM, while only 2 out of 5 integrin $\beta 1^{\text {low/- }}$ mice developed LNM. Chi-Square analysis shows the 2 populations of cells have significantly different metastatic capability $(\mathrm{p}<0.05)$.

\section{Effect of knocking-down integrin $\beta 1$ on invasion and metastasis of HNSCC}

To assess the role that integrin $\beta 1$ plays in invasion of HNSCC, we knocked down integrin $\beta 1$ expression using the pLVTHM lentivirus system in 37B and M4E cells and named the integrin $\beta 1$ knock-down cells 37B-15 and M4E-15 (Fig 2D). Matrigel invasion assay was performed as described above on the integrin $\beta 1$ knock-down cells and the control cells. Knock-down of integrin $\beta 1$ significantly reduced the invasive ability of both M4E cells and PCI-37B cells (Fig 2E and Fig 2F). Fig 2G shows the invasive PCI-37B cells at the lower part of the chamber membrane. To determine if integrin $\beta 1$ is essential in the process of HNSCC metastasis in vivo, we injected M4E control and M4E/integrin $\beta 1 /$ knock-down cells (M4E-15) into nude mice. Mice were sacrificed 4 weeks after the tumors were observed. Cervical lymph nodes and lungs were collected for H\&E-staining to identify metastasis in these two organs. Within the 2 groups, 7 out of 9 mice injected with control M4E cells developed LNM, while none of the mice in the group injected with integrin $\beta 1 /$ knock-down cells developed LNM ( $<<0.001$ by Chi Square analysis). 4 out 9 mice injected with control cells developed lung metastases, while no lung metastasis was observed in the group injected with integrin $\beta 1 /$ knock-down cells $(\mathrm{p}<0.05)$. Fig $3 \mathrm{~A}$ and $3 \mathrm{C}$ show the lack of lymph node and lung metastasis in mice injected with M4E-15 cells, while Fig 3B and 3D show the metastatic cancer cells in the lymph node and lung in mice injected with M4E control cells. Fig $3 \mathrm{E}$ and $3 \mathrm{~F}$ show the integrin $\beta 1$ staining of xenograft tumors from M4E-15 and M4E control injected mice, respectively. Our xenograft model also showed that M4E control cells developed significantly larger tumors $(0.69 \pm 0.19 \mathrm{~g})$ than M4E- 15 cells $(0.31 \pm 0.18 \mathrm{~g})$, as shown in Fig 3H and 3I ( $<<0.002$ by student T-test).

\section{Effect of integrin $\beta 1$ on MMP-2 activity}

To address how integrin $\beta 1$ affects the invasion ability of cancer cells, we next performed a gelatin gel zymography assay to determine which MMP is affected after integrin $\beta 1$ knockdown. Our results show that integrin $\beta 1$ knock-down reduced the invasion capability, likely by hampering MMP-2 activity in vitro, while MMP-9 activity was not detectable based on the position of the band. Two integrin $\beta 1$-knockdown cell lines, PCI-37B-15 and M4E-15, were tested for MMP-2 activity in vitro with and without fibronectin, a ligand for integrin $\beta 1$. In both PCI-37B-15 and M4E-15 cells, knock-down of integrin $\beta 1$ significantly reduced 
MMP-2 activity induced by fibronectin ( $\mathrm{p}<0.01, \mathrm{n}=3$ ). Fig 4A shows that MMP-2 activity in both M4E and PCI-37B control cells was increased after fibronectin treatment, however this inductive effect of fibronectin was significantly reduced in integrin $\beta 1$ knock-down cells. As shown by the zymography assay, only the active form of MMP-2 (62-66KD) was reduced by knocking down integrin $\beta 1$. MMP-2 activity was not observed in non-fibronectin treated cells. Fig 4C and Fig 4D show that the density of activated MMP-2 bands in M4E (Fig 4C) and PCI-37B cells (Fig 4D) treated with fibronectin was $3.97 \pm 0.55$ and $5.03 \pm 0.60$ times higher than that in integrin $\beta 1$ knock-down cells with the same treatment.

Western blot results also indicate that after integrin $\beta 1$ was knocked down, MMP-2 expression (active form) was reduced, but no change in MT1-MMP was observed (Fig 4B). We also performed immunostaining of MMP- 2 in the samples from both integrin $\beta 1$ wild type xenograft tumors and integrin- $\beta 1$ knock-down xenograft tumors. The results showed that 5 of 6 integrin $\beta 1$ wild type xenograft tumors expressed MMP-2, while only 2 out of 6 integrin $\beta 1$ knock-down xenograft tumors expressed MMP-2 (supplemental data Fig S3). Similar to the Western blot analyses, we observed no change in MT1-MMP immunostaining between the integrin $\beta 1$ wild type and integrin- $\beta 1$ knock-down xenograft tumors. MMP-9 was not detectable in any xenograft tumors (supplemental data Fig S3).

To further understand the function of MMP 2 in cell invasion, we overexpressed MMP-2 in M4E integrin $\beta 1$ knock-down cells (M4E-15). Increased invasion capability of M4E-15 cells was observed (supplemental data Fig S4). We next addressed the nature of the regulatory relationship between MMP- 2 and integrin $\beta 1$. It has been shown that ERK activation is required for invasion of tumor cells through MMP-2 activity (25). We also found that knock-down of integrin $\beta 1$ reduced ERK activity in HNSCC cell lines (supplemental data Fig S5), suggesting that integrin $\beta 1$ may take part in ERK activation and sequentially, MMP-2 activation.

\section{Discussion}

Metastasis is the hallmark of malignant tumors and the primary cause of cancer patient death. Lymph node metastasis of HNSCC is associated with poor prognosis. Therefore, better understanding of the molecular mechanisms underlying the metastasis of $\mathrm{HNC}$ and the identification of predictive metastatic and prognostic markers will contribute significantly to our ability to predict and guide the treatment of this disease. In our current study, we aimed to determine the role of integrin $\beta 1$ in metastasis of HNSCC from several perspectives. First, we found a significantly higher expression level of integrin $\beta 1$ in the primary tumors from patients with metastasis than those without, indicating that integrin $\beta 1$ is a potential metastatic marker for HNSCC. Most interestingly, we found that in patients with metastatic tumors, low integrin $\beta 1$ expression correlated significantly with longer overall survival, suggesting that integrin $\beta 1$ may serve as a prognostic marker for this group of patients. We next demonstrated that the integrin $\beta 1^{+/ \text {high }}$ population of M4E cells has a significantly higher metastatic rate in a xenograft animal model than the integrin $\beta 1^{-/ \text {low }}$ counterpart. This result further confirmed the potential of integrin $\beta 1$ as a metastatic marker. Integrin $\beta 1$ knock-down in highly metastatic M4E cells significantly impaired their metastatic rate in a xenograft animal model. None of the 10 mice injected with integrin $\beta 1$ knock-down cells developed lymph node or lung metastasis, which was significantly different from the control cells. This in vivo result clearly implicates integrin $\beta 1$ not only as a potential metastatic marker but also as having a significant role in the regulation of HNSCC metastasis, which has not been reported in HNSCC before.

It is crucial to understand the function that integrin $\beta 1$ plays in the metastasis process, although the involvement of integrin $\beta 1$ in cell adhesion is well known. We tested whether 
integrin $\beta 1$ regulates HNSCC metastasis by affecting the invasive ability of cancer cells. Through in vitro studies, we showed that knock-down of integrin $\beta 1$ significantly reduced fibronectin-stimulated activity of MMP-2, an enzyme of the matrix metalloproteinase (MMP) family. MMP-2 is a $72 \mathrm{kDa}$, type IV collagenase that is involved in the breakdown of extracellular matrix in normal physiological processes, such as embryonic development, reproduction, and tissue remodeling, as well as in disease processes, such as arthritis and metastasis (22-24). Our results suggest that MMP-2 activity requires integrin $\beta 1$.

Furthermore, our finding that knock-down of integrin $\beta 1$ reduced ERK activity in HNSCC cell lines suggests that integrin $\beta 1$ may take part in ERK activation and sequentially, MMP-2 activation, consistent with the demonstration that ERK activation is required for invasion of tumor cells through MMP-2 activity (25). On the other hand, MMP-2 is known to be activated by membrane type-1 MMP (MT1-MMP). MT1-MMP cleaves the N-terminal prodomain of pro-MMP-2, allowing it to mature into the fully active MMP-2 enzyme (26). It has been reported that polarized trafficking of MT1-MMP can be induced by integrin $\beta 1$ mediated adhesion to collagen, and is required for protease localization at invasive structures (27). Since we did not observe changes in MT1-MMP expression after knocking down integrin $\beta 1$, further study is warranted to define the regulation pathway involving integrin $\beta 1$, MT1-MMP, and MMP-2.

Integrin $\beta 1$ is reported to contribute to epithelial-mesenchymal transition (EMT) through interaction with TGF- $\beta 1$ (28) and is involved in several signaling pathways supporting metastasis. In prostate, colon, and $\mathrm{HNC}$, integrin $\beta 1$ was reported to be associated with a cell population with the characteristics of EMT, metastasis, and/or cancer stem-like cells (24, 25, 29, 30). In our study, both M4E and PCI-37B cells showed EMT features including loss of E-cadherin and expression of vimentin. Reducing integrin $\beta 1$ did not promote mesenchymal epithelial transition (MET), suggesting other molecular events are involved in the process (data not shown). However, our study clearly showed that in both EMT (M4E) and nonEMT cells (212LN), there is an integrin $\beta 1$ positive/high population which is prone to metastasize more easily than the negative/low population, supporting the metastasis subpopulation concept observed in breast and colon cancers.

Many integrins ( $a 5 \beta 1, \alpha 8 \beta 1, \alpha v \beta 1, a v \beta 3$, and $\alpha 4 \beta 1)$ can recognize and bind to fibronectin via the Arg-Gly-Asp (RGD) motif (31). Among these integrins, a $5 \beta 1$ is particularly efficient in mediating fibronectin matrix assembly (32-34) which is important for cell spreading. Since fibronectin clearly increased the invasive ability of the cancer cells in our system, we suspect it is probably a 5 paired with $\beta 1$ in cancer cells that drives the cancer cells to metastasize. A recent publication also reported for the first time that loss of an epithelial marker E-cadherin promoted ovarian cancer metastasis via a $5 \beta 1$ integrins, suggesting integrin $\beta 1$ could be a therapeutic target for metastatic disease (35). Van Waes et $a l$, reported enhanced expression of a $6 \beta 4$ integrin in progression of HNSCC (13). $a 6 \beta 4$ as well as a $2 \beta 1$ and $a 3 \beta 1$ mentioned in this article are mainly laminin receptors. Siqueria et al also showed a laminin derived peptide, AG73, regulated invasion through the integrin $\beta 1$ MMP-9 pathway in OSCC cells (36). However, we did not observe an effect of laminin on integrin $\beta 1$ associated invasion and MMP-9 activation in our cell line models (data not shown), suggesting that the alpha integrin subunit which binds fibronectin may play the major role in our cell line models. It is obvious that fibronectin is not the only primary mediator of the effects of integrin $\beta 1$ in HNSCC. The two cell line models may only represent a subpopulation of HNSCC cells.

Another interesting finding of our work is that both the integrin $\beta 1^{+/ \text {high }}$ population and control cells developed significantly larger tumors than their integrin $\beta 1^{-/ \mathrm{low}}$ and integrin $\beta 1$ knock-down counterparts, respectively. We did not observe reduced proliferation in vitro for either integrin $\beta 1^{-/ \text {low }}$ or integrin $\beta 1$ knock-down cells (supplemental data Fig S6), 
suggesting that the microenviroment in vivo leads to this difference in tumor growth. The tumor microenviroment has been shown to play an important role in tumor progression (28, 37-39). The roles of integrins in the cancer microenvironment have also been discussed (29, 30 ). It will be interesting and necessary to utilize 3-D culture systems and animal models to further investigate the interaction between cancer cells and the stroma surroundings involving integrin $\beta 1$.

\section{Supplementary Material}

Refer to Web version on PubMed Central for supplementary material.

\section{Acknowledgments}

This study was supported by a GCC Distinguished Scholar Award and NIH/NCI R21 CA125062 to Z(G)C. We thank Dr. Anthea Hammond for her critical reading of the manuscript.

\section{References}

1. Jemal A, Bray F, Center MM, Ferlay J, Ward E, Forman D. Globe Cancer statistics. CA Cancer J Clin. 2011; 61:69-90. [PubMed: 21296855]

2. Parkin DM, Bray F, Ferlay J, Pisani P. Global cancer statistics. CA Cancer J Clin. 2005; 55:74-108. [PubMed: 15761078]

3. Jemal A, Siegel R, Ward E, Hao Y, Xu J, Thun M. Cancer Statistics, 2010. CA Cancer J Clin. 2009; 60:277-300. [PubMed: 20610543]

4. Bacac M, Stamenkovic I. Metastatic cancer cell. Annu. Rev. Pathol. Mech. Dis. 2008; 3:221-247.

5. Weinberg, RA. The biology of cancer. New York: Garland Science; 2007.

6. Fidler IJ. The pathogenesis of cancer metastasis: the 'seed and soil' hypothesis revisited. Nat Rev Cancer. 2003; 3:453-458. [PubMed: 12778135]

7. Gupta GP, Massague J. Cancer metastasis: Building a framework. Cell. 2006; 127:679-695. [PubMed: 17110329]

8. Felding-Habermann B. Integrin adhesion receptors in tumor metastasis. Clinical Experimental Metastasis. 2003; 20:203-213. [PubMed: 12741679]

9. Goodfellow PJ, Nevanlinna HA, Gorman P, Sheer D, Lam G, Goodfellow PN. Assignment of the gene encoding the beta-subunit of the human fibronectin receptor (beta-FNR) to chromosome 10p11.2. Ann Hum Genet. 1989; 53(Pt 1):15-22. [PubMed: 2524991]

10. Zhang X, Su L, Pirani AA, Wu H, Zhang H, Shin DM, et al. Understanding metastatic HNSCC cells from unique genotypes to phenotypes with the aid of an animal model and DNA microarray analysis. Clin Exp Metastasis. 2006; 23:209-222. [PubMed: 17028921]

11. Zhang X, Liu Y, Gilcrease MZ, Yuan XH, Clayman GL, Adler-Storthz K, et al. A lymph node metastatic mouse model reveals alterations of metastasis-related gene expression in metastatic human oral carcinoma sublines selected from a poorly metastatic parental cell line. Cancer. 2002; 95:1663-1672. [PubMed: 12365014]

12. Taverna D, Ullman-Cullere M, Rayburn H, Bronson RT, Hynes RO. A test of the role of alpha5 integrin/fibronectin interactions in tumorigenesis. Cancer Res. 1998; 58:848-853. [PubMed: 9485045]

13. VanWaes C, Surh DM, Chen Z, Kirby M, Rhim J, Brager R, et al. Increase in Suprabasilar Integrin adhesion molecule expression in human epidermal neoplasms accompanies increased peoliferatin occurring with immortalization and tumor progression. Cancer Res. 1995; 55:5434-5444. [PubMed: 7585613]

14. Koivisto L, Grenman R, Heino J, Larjava H. Integrins alpha5beta1, alphavbeta1, and alphavbeta6 collaborate in squamous carcinoma cell spreading and migration on fibronectin. Exp Cell Res. 2000; 255(1):10-17. [PubMed: 10666329]

15. Chirco R, Liu XW, Jung KK, Kim HR. Novel functions of TIMPs in cell signaling. Cancer Metastasis Rev. 2006; 25:99-113. [PubMed: 16680576]

Clin Cancer Res. Author manuscript; available in PMC 2013 September 01. 
16. Munshi HG, Stack MS. Reciprocal interactions between adhesion receptor signaling and MMP regulation. Cancer Metastasis Rev. 2006; 25:45-56. [PubMed: 16680571]

17. Maity G, Fahreen S, Banerji A, Roy Choudhury P, Sen T, Dutta A, et al. Fibronectin-integrin mediated signaling in human cervical cancer cells (SiHa). Mol Cell Biochem. 2010; 336:65-74. [PubMed: 19816757]

18. Li P, Zhao ZJ, Liu FY, Sun LY, Ding X, Zhang WZ, et al. The chemokine receptor 7 regulates cell adhesion and migration via beta1 integrin in metastatic squamous cell carcinoma of the head and neck. Oncol Rep. 2010; 24:989-995. [PubMed: 20811680]

19. Muller S, Su L, Tighiouart M, Saba N, Zhang H, Shin DM, et al. Distinctive E-cadherin and epidermal growth factor receptor expression in metastatic and nonmetastatic head and neck squamous cell carcinoma: predictive and prognostic correlation. Cancer. 2008; 113:97-107. [PubMed: 18473353]

20. Klabfleisch, JD.; Prentice, RL. The statistical analysis of failure time data. John Wiley and Sons; New York: 1980.

21. Cox DR. Regression Models and Life Tables. Journal of the Royal Statistical Society Series. 1972 B; 34:187-220.

22. Morgunova E, Tuuttila A, Bergmann U, Tryggvason K. Structural insight into the complex formation of latent matrix metalloproteinase 2 with tissue inhibitor of metalloproteinase. Proc. Natl. Acad. Sci. U. S. A. 2002; 99:7414-7419. [PubMed: 12032297]

23. Martignetti JA, Aqeel AA, Sewairi WA, Boumah CE, Kambouris M, Mayouf SA, et al. Mutation of the matrix metalloproteinase 2 gene (MMP2) causes a multicentric osteolysis and arthritis syndrome. Nature Genetics. 2001; 28:261-265. [PubMed: 11431697]

24. Köhrmann A, Kammerer U, Kapp M, Dietl J, Anacker J. Expression of matrix metalloproteinases (MMPs) in primary human breast cancer and breast cancer cell lines: New findings and review of the literature. BMC Cancer. 2009; 9:188. [PubMed: 19531263]

25. Kim KH, Cho YS, Park JM, Yoon SO, Kim KW, Chung AS. Pro-MMP-2 activation by the PPAR $\gamma$ agonist, ciglitazone, induces cell invasion through the generation of ROS and the activation of ERK. FEBS Letters. 2007; 581:3303-3310. [PubMed: 17597617]

26. Sato H, Takino T, Okada Y, Cao J, Shinagawa A, Yamamoto E, et al. TIMP-2 Promotes Activation of Progelatinase A by Membrane-type 1 Matrix Metalloproteinase Immobilized on Agarose Beads. Nature. 1994; 370:61-65. [PubMed: 8015608]

27. Sato H, Takino T, Miyamori H. Roles of membrane-type matrix metalloproteinase-1 in tumor invasion and metastasis. Cancer Sci. 2005; 96:212-217. [PubMed: 15819718]

28. Kuhn NZ, Tuan RS. Regulation of stemness and stem cell niche of mesenchymal stem cells: implications in tumorigenesis and metastasis. J Cell Physiol. 2010; 222:268-277. [PubMed: 19847802]

29. Alphonso A, Alahari SK. Stromal cells and integrins: conforming to the needs of the tumor microenvironment. Neoplasia. 2009; 11:1264-1271. [PubMed: 20019834]

30. Desgrosellier JS, Cheresh DA. Integrins in cancer: biological implications and therapeutic opportunities. Nat Rev Cancer. 2010; 10:9-22. [PubMed: 20029421]

31. Danen EH, Sonnenberg A. Integrins in regulation of tissue development and function. J. Pathol. 2003; 201:632-641. [PubMed: 14648669]

32. Wennerberg K, Lohikangas L, Gullberg D, Pfaff M, Johansson S, Fassler R. Beta 1 integrindependent and -independent polymerization of fibronectin. J. Cell Biol. 1996; 132:227-238. [PubMed: 8567726]

33. Wu C, Bauer JS, Juliano RL, McDonald JA. The alpha 5 beta 1integrin fibronectin receptor, but not the alpha 5 cytoplasmic domain, functions in an early and essential step in fibronectin matrix assembly. J. Biol. Chem. 1993; 268:21883-21888. [PubMed: 7691819]

34. Yang JT, Hynes RO. Fibronectin receptor functions in embryonic cells deficient in a $5 \beta 1$ integrin can be replaced by aV integrins. Mol. Biol. Cell. 1996; 7:1737-1748. [PubMed: 8930896]

35. Sawada K, Mitra AK, Radjabi AR, Bhaskar V, Kistner EO, Tretiakova M, et al. Loss of E-cadherin promotes ovarian cancer metastasis via alpha 5-integrin, which is a therapeutic target. Cancer Res. 2008; 68:2329-2339. [PubMed: 18381440] 
36. Siqueira AS, Gama-de-Souza LN, Arnaud MV, Pinheiro JJ, Jaeger RG. Laminin-derived peptide AG73 regulates migration, invasion, and protease activity of human oral squamous cell carcinoma cells through syndecan-1 and beta1 integrin. Tumor Biol. 2010; 31:46-58.

37. Klein JD, Grandis JR. The molecular pathogenesis of head and neck cancer. Cancer Biol Ther. 2010; 9:1-7. [PubMed: 20038820]

38. Joyce JA, Pollard JW. Microenvironmental regulation of metastasis. Nat Rev Cancer. 2009; 9:239_ 252. [PubMed: 19279573]

39. Strand DW, Franco OE, Basanta D, Anderson AR, Hayward SW. Perspectives on Tissue Interactions in Development and Disease. Cur Mol Med. 2009; 10:95-112. 


\section{Statement of Translational Relevance}

Metastasis is one of the major factors underlying the poor prognosis of head and neck cancer. Understanding the progression of head and neck cancer from the primary site to the lymph node and distant organs will facilitate development of new treatment strategies against this disease. Though integrin $\beta 1$ is known to contribute to invasion, its prognostic value and role played in metastasis of head and neck cancer have not been elucidated. The current study examined integrin $\beta 1$ expression in human head and neck cancer tissues and tested whether blocking integrin $\beta 1$ could reduce the incidence of lymph node and lung metastases in an animal model. Our results clearly indicated that integrin $\beta 1$ was not only a potential marker of metastasis, but also played a significant role in the regulation of head and neck cancer metastasis. This study opens the possibilities of using integrin $\beta 1$ for early detection of metastatic lesions and of targeting this protein for the treatment of metastatic disease. 

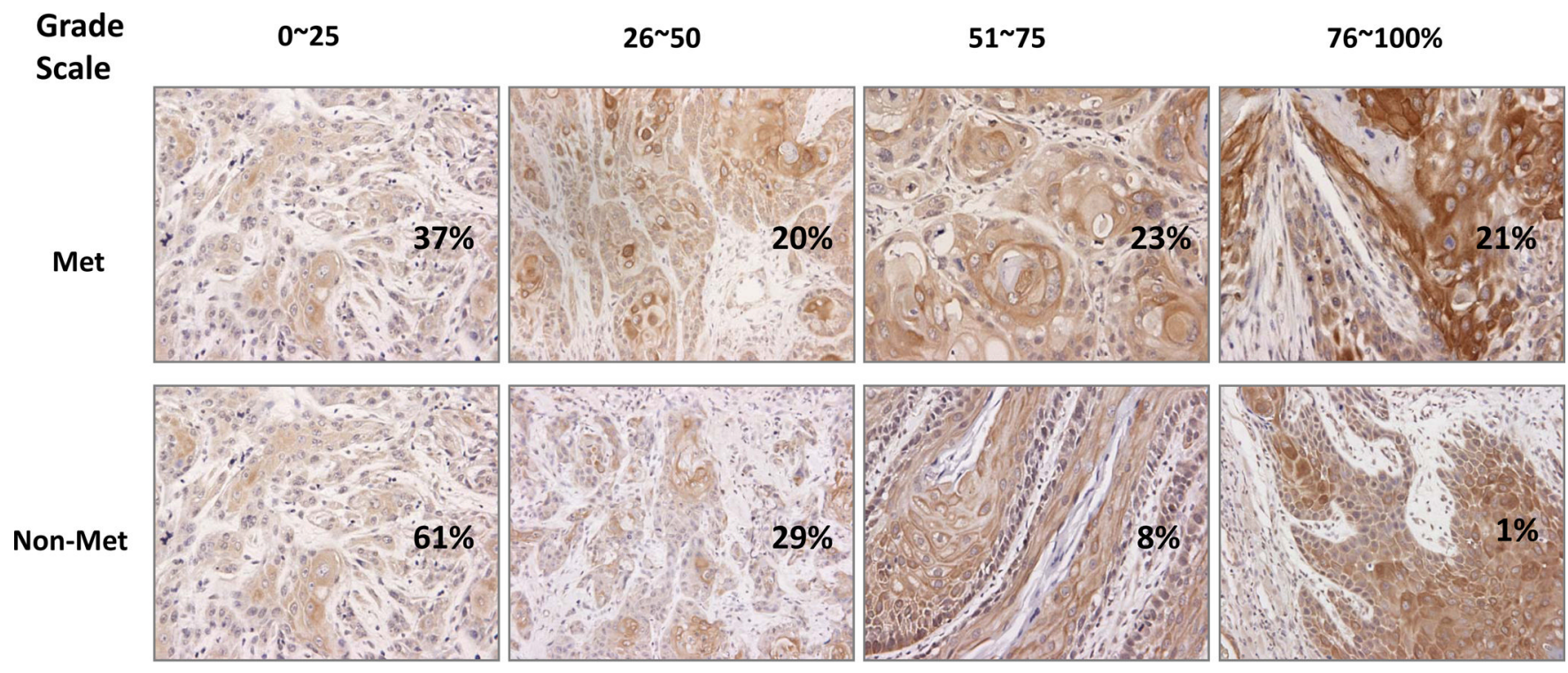

Negative CNT

Positive CNT
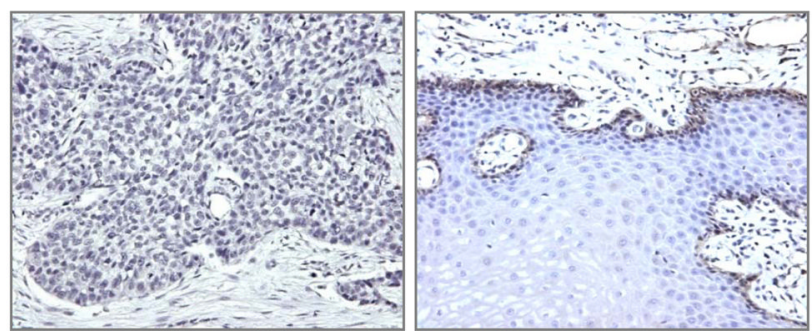

Lymph Node

Fig 1.

Integrin $\beta 1$ expression pattern in HNSCC tissues from patients with and without metastasis. IHC analysis of integrin $\beta 1$ in HNSCC samples shows membrane and cytoplasmic expression patterns. Of the patients without metastasis, $62 \%$ had $0 \sim 25 \%$ positive staining, $29 \%$ had $26 \sim 50 \%$ positive staining, $8 \%$ had $51 \sim 75 \%$ positive staining, and only $1 \%$ of patients had 76 100\% positive staining, while of the patients with metastasis, $37 \%$ had $0 \sim 25 \%$ positive staining, $20 \%$ had $25 \sim 50 \%$ positive staining, $23 \%$ had $51 \sim 75 \%$ positive staining, and $21 \%$ of patients had $76 \sim 100 \%$ positive staining. Tissue stained with IgG only and normal epithelium staining were used as the negative and the positive controls, respectively. Metastatic lymph node shows a similar staining as its primary counterpart (Magnification $200 \times$ ). 
A

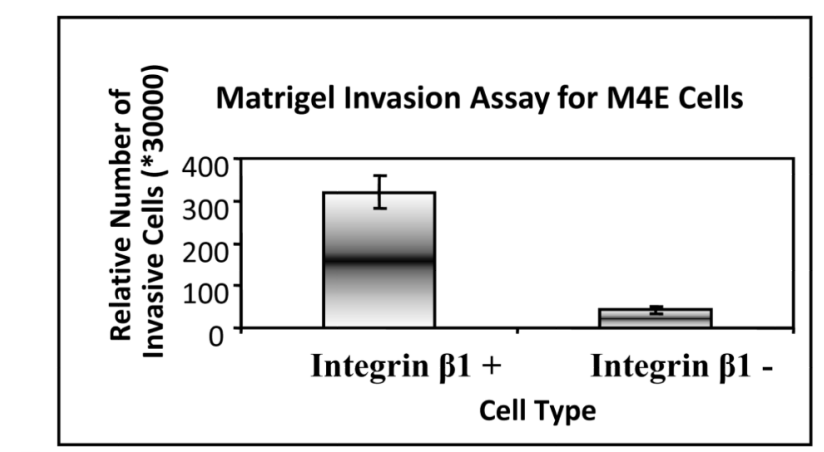

B

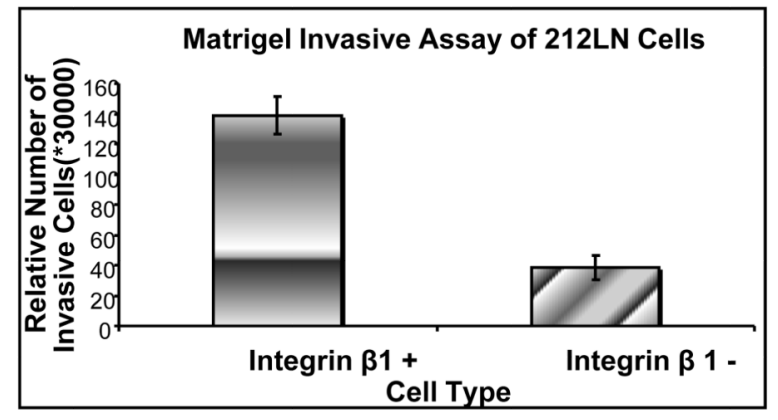

C
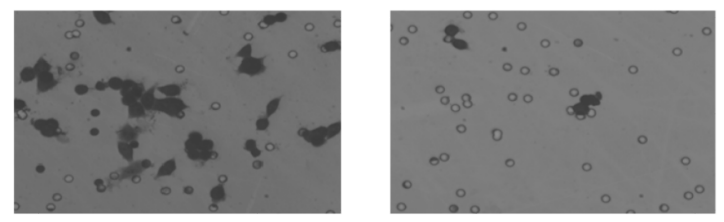

M4E Integrin $\beta 1+\quad$ M4E Integrin $\beta 1-$
D 37B-15 37BCNT

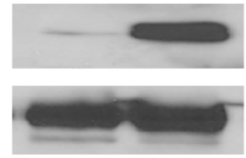
Integrin $\beta 1$ M4E-15 M4ECNT

E

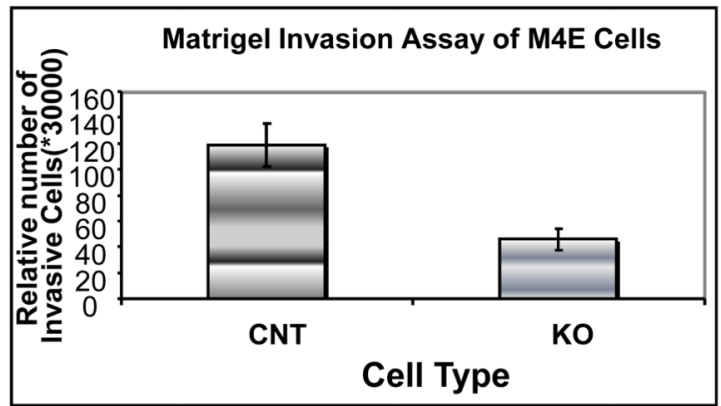

$\mathbf{F}$

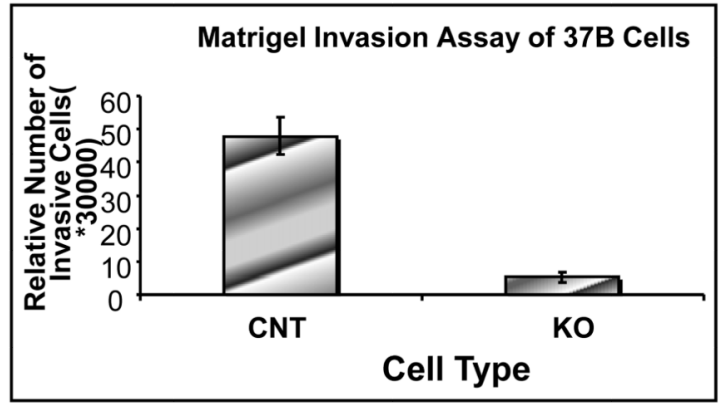

G
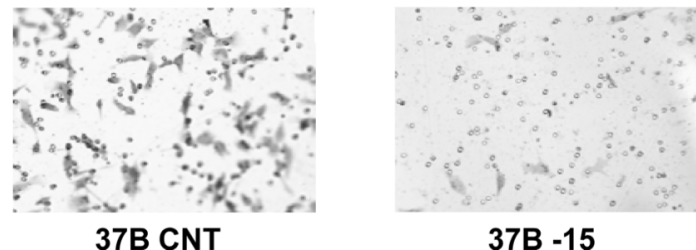

37B -15

Fig 2.

Integrin $\beta 1$ affects the invasive ability of SCCHN cell lines. (A) and (B) show that in both M4E (A) and 212 LN (B) cells, the integrin $\beta 1$-positive population shows a significantly higher invasive ability than the integrin $\beta 1$-negative population. (C) shows there are more invasive integrin $\beta 1^{+} \mathrm{M} 4 \mathrm{E}$ than integrin $\beta 1^{-} \mathrm{M} 4 \mathrm{E}$ cells at the lower part of the chamber membrane (Magnification $200 \times$ ). (D) shows integrin $\beta 1$ was knocked down using integrin $\beta 1$-specific shRNA expressed by pLVTHM lentivirus vector in PCI-37B and M4E cells to create M4E-15 and PCI-37B-15 cells, respectively. (E) and (F) show knock-down of integrin $\beta 1$ expression significantly reduced the invasive ability of M4E (E) and PCI-37B (F) cells. The analysis of invasive cells from each cell line was repeated 3 times. $(\mathrm{G})$ shows more invasive 37B control cells than 37B-15 integrin $\beta 1$ knock-down cells on the lower part of the chamber membrane (Magnification $200 \times$ ). CNT $=$ control cells; $\mathrm{KO}=$ integrin $\beta 1$ knock-down cells. 

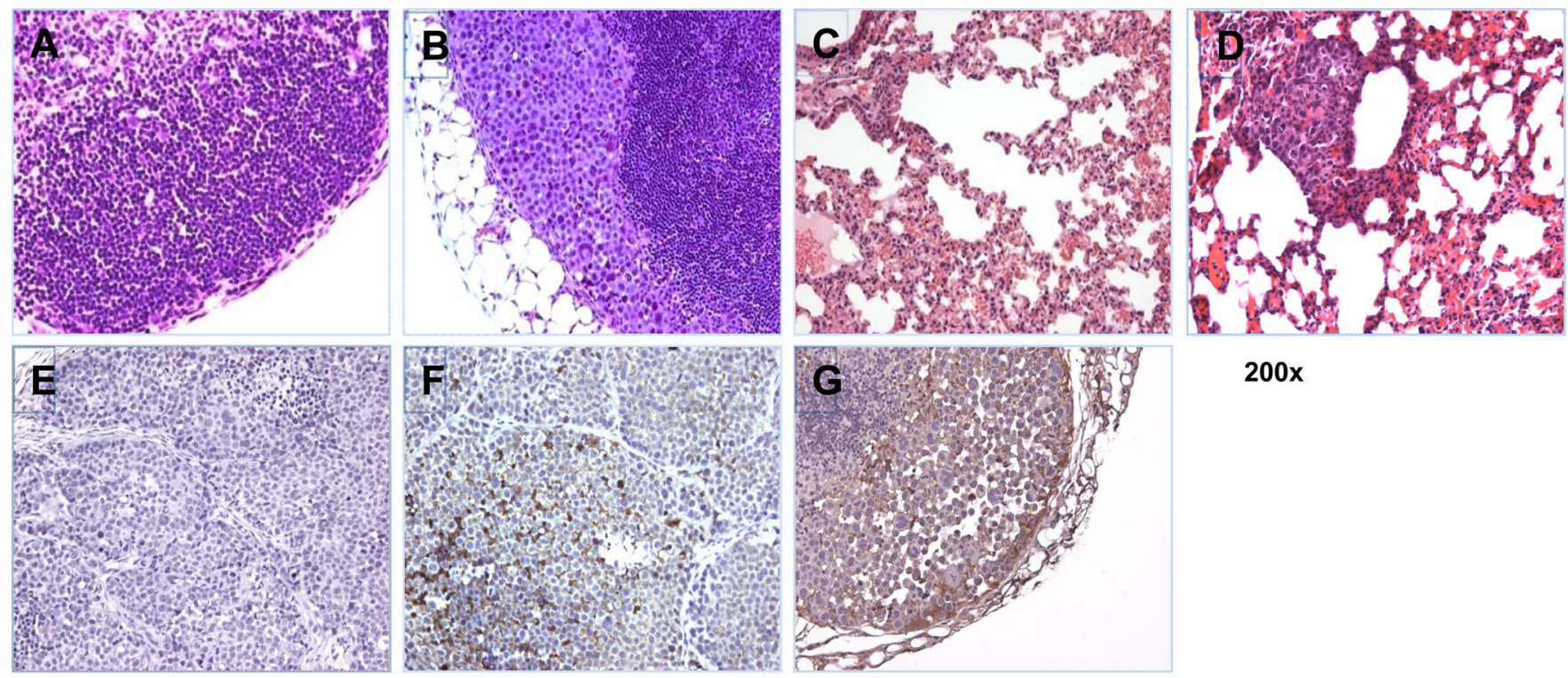

$200 x$

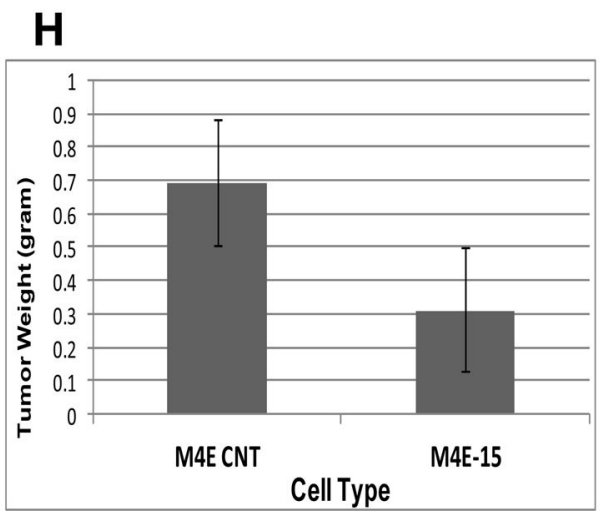

I

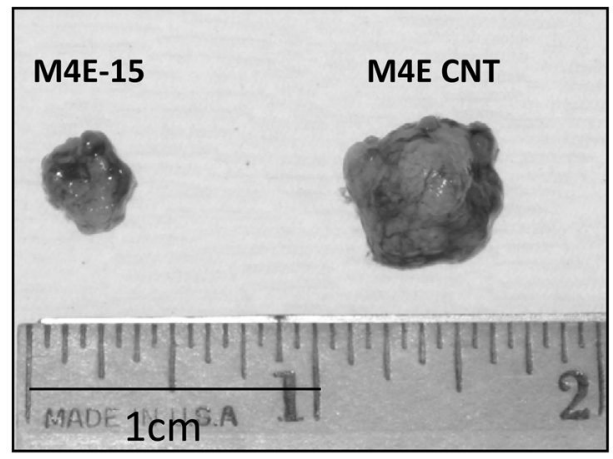

Fig 3.

M4E control cells, but not their integrin $\beta 1$ knock-down counterparts, developed lymph node and lung metastasis. No metastatic cancer cells were observed in lymph node (A) and lung (C) in M4E-15 injected mice, while tumor developed from the control M4E cells further migrated to both lymph node (B) and lung (D). IHC staining of xenograft tumor tissues using an integrin $\beta 1$-specific antibody showed no integrin $\beta 1$ expression in xenograft tumor developed from M4E-15 cells (E), and confirmed integrin $\beta 1$ expression in control M4E cells (F). (G) shows integrin $\beta 1$ expression in metastatic lesion (lymph node metastatic tumor) (Magnification $200 \times$ ). (H) shows control M4E cells developed significantly larger tumor in the xenograft model compared to their integrin $\beta 1$ knock-down counterparts. Student's t-test was performed to determine the difference in weight between the two groups. (I) shows control M4E developed larger and heavier tumors $(0.69 \pm 0.19 \mathrm{~g})$ than M4E-15 cells $(0.31 \pm 0.18 \mathrm{~g})(\mathrm{p}<0.002)$. 
A
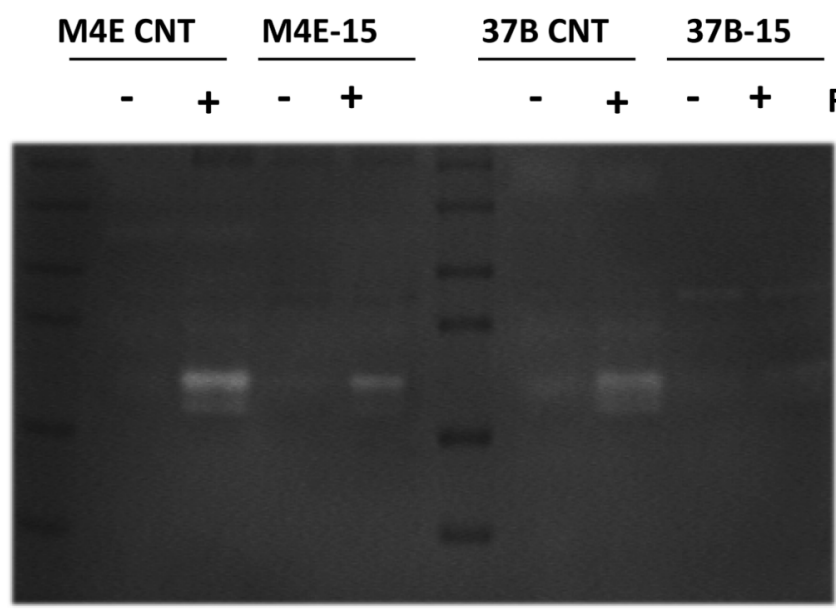

C

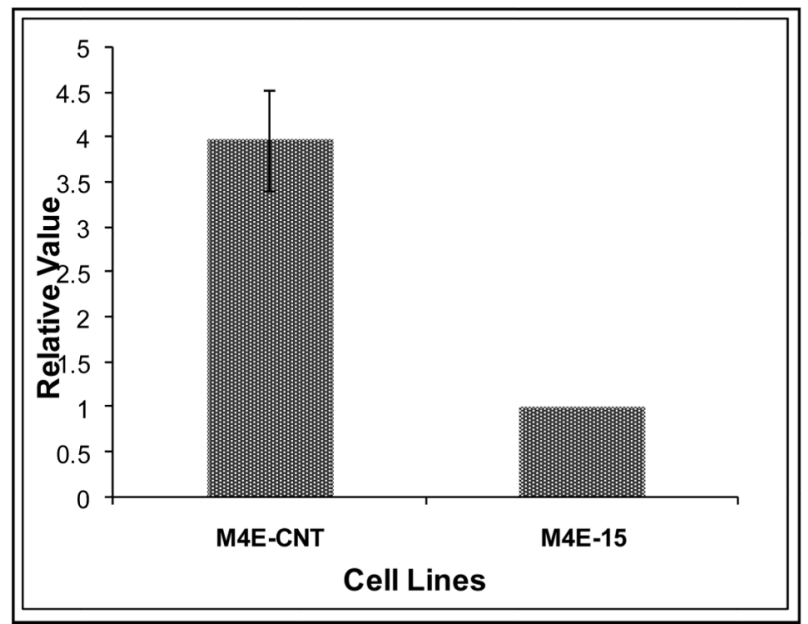

B

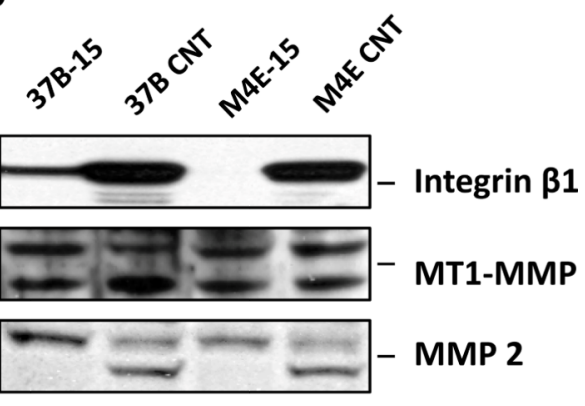

$-50 K D$

Fibronectin

$-100 K D$

$-75 K D$

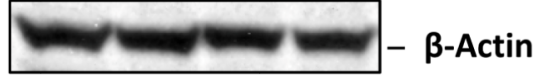

Fig 4.

Fibronectin stimulates MMP-2 activity only in control HNSCC cell lines, and not in their integrin $\beta 1$ knock-down counterparts. (A) shows that MMP-2 activity in both M4E and PCI-37B cells was increased after fibronectin treatment $(20 \mu \mathrm{g} / \mathrm{mL})$, however the induction effect of fibronectin was eliminated in integrin $\beta 1$ knock-down cells. As shown by the zymography assay, only the active form of MMP-2 (62-66KD) was reduced. MMP-2 activity was not observed in non-fibronectin treated cells. No MMP-9 band was found in this test. The density of activated MMP-2 bands in M4E and PCI-37B control cells was $3.97 \pm 0.55$ (C) and 5.03 \pm 0.60 (D) times higher than that in the integrin $\beta 1$ knock-down cells, respectively. This figure represents 1 of 3 experiments. (B) Western blot analysis showed that no change of MT1-MMP was observed in integrin $\beta 1$ knock-down cells (M4E-15 and 37B-15) comparing to wild type control cells. However, active MMP-2 was reduced in integrin $\beta 1$ knocked-down cells. 


\begin{tabular}{|c|c|c|c|c|c|c|c|c|c|c|c|c|c|c|c|c|c|c|c|c|c|c|c|c|c|c|c|c|}
\hline 竞 & & 2 & 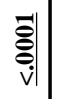 & & $\begin{array}{l}0 \\
\text { ồ } \\
\text { of } \\
0 \\
0\end{array}$ & & $\begin{array}{l}\text { o } \\
\text { त̂̀ } \\
\text { on }\end{array}$ & & $\stackrel{\infty}{\stackrel{\infty}{*}}$ & & & 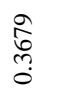 & & & & $\begin{array}{l}\bar{\delta} \\
\dot{v} \\
\dot{v}\end{array}$ & & & & 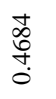 & & $\begin{array}{l}\frac{0}{n} \\
\stackrel{n}{0}\end{array}$ & & & 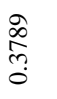 & & & $\begin{array}{l}\frac{a}{2} \\
\frac{2}{2}\end{array}$ \\
\hline 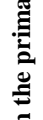 & 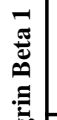 & 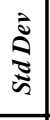 & $\begin{array}{l}0 \\
n \\
n \\
\check{n} \\
\vdots\end{array}$ & $\begin{array}{l}\vec{I} \\
\vec{i}\end{array}$ & $\left|\begin{array}{l}\Delta \\
0 \\
o \\
\dot{\nu}\end{array}\right|$ & $\begin{array}{l}\hat{n} \\
\stackrel{6}{0} \\
\stackrel{i}{0}\end{array}$ & 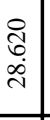 & $\begin{array}{l}\overrightarrow{0} \\
n \\
c \\
c\end{array}$ & $\begin{array}{l}5 \\
\stackrel{1}{i} \\
\grave{i}\end{array}$ & $\begin{array}{l}\overrightarrow{\bar{T}} \\
\stackrel{J}{J}\end{array}$ & $\begin{array}{l}8 \\
0 \\
0 \\
\stackrel{i}{0}\end{array}$ & $\begin{array}{l}\bar{a} \\
\vec{\lambda} \\
\text { d }\end{array}$ & 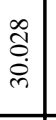 & $\begin{array}{l}8 \\
\stackrel{1}{0} \\
\dot{8}\end{array}$ & 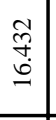 & $\begin{array}{l}0 \\
n \\
n \\
\vdots \\
\end{array}$ & $\begin{array}{c}\stackrel{8}{0} \\
\stackrel{m}{m} \\
\dot{m}\end{array}$ & $\begin{array}{l}0 \\
f \\
f \\
\dot{f} \\
i\end{array}$ & $\begin{array}{c}\infty \\
\stackrel{\infty}{\sim} \\
\dot{m}\end{array}$ & $\begin{array}{l}0 \\
\vec{f} \\
\dot{J} \\
\dot{J}\end{array}$ & $\begin{array}{l}\vec{\infty} \\
\stackrel{\vec{\lambda}}{\vec{\lambda}}\end{array}$ & 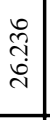 & $\begin{array}{l}m \\
\vec{b} \\
\stackrel{d}{i}\end{array}$ & & $\begin{array}{l}\infty \\
\infty \\
0 \\
\dot{m} \\
0\end{array}$ & 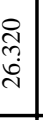 & 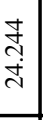 & $\begin{array}{l}\text { ¿े } \\
\text { ते } \\
\text { ते }\end{array}$ \\
\hline 居 & 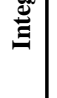 & $\Xi$ & $\begin{array}{l}\tilde{c} \\
\hat{c} \\
\dot{d}\end{array} \mid$ & $\begin{array}{l}\text { 芯 } \\
\text { gु }\end{array}$ & $\begin{array}{l}\vec{\delta} \\
\dot{\delta} \\
\dot{m}\end{array}$ & 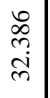 & $\begin{array}{l}\mathscr{0} \\
0 \\
\stackrel{0}{0} \\
\stackrel{0}{0}\end{array}$ & $\begin{array}{l}\vec{m} \\
\vec{j}\end{array}$ & $\begin{array}{l}\infty \\
\vdots \\
\vdots \\
\vdots \\
\vdots\end{array}$ & $\begin{array}{l}\text { ते } \\
\text { હે }\end{array}$ & 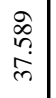 & 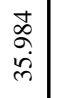 & 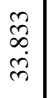 & 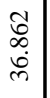 & 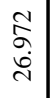 & $\begin{array}{l}\stackrel{\tilde{D}}{2} \\
\dot{d}\end{array}$ & $\begin{array}{l}+ \\
\stackrel{\Delta}{ } \\
\dot{\gamma}\end{array}$ & $\begin{array}{l}\text { I } \\
\text { J } \\
\text { J }\end{array}$ & $\begin{array}{l}\text { तु } \\
\text { वें } \\
\text { | }\end{array}$ & $\begin{array}{c}\stackrel{q}{q} \\
\stackrel{\infty}{m} \\
\dot{m}\end{array}$ & 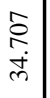 & $\begin{array}{l}\hat{i} \\
\hat{i} \\
\text { r. }\end{array}$ & $\begin{array}{l}\frac{8}{0} \\
\dot{q} \\
\end{array}$ & & $\begin{array}{l}\stackrel{\infty}{ } \\
\vec{m} \\
m\end{array}$ & 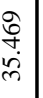 & 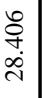 & 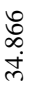 \\
\hline 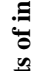 & & $z$ & a & 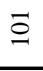 & $\stackrel{\ominus}{\varrho}$ & 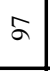 & $F$ & $\grave{\Xi}$ & $\stackrel{\infty}{m}$ & 5 & 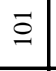 & 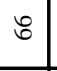 & 8 & ते & $\stackrel{i}{\circ}$ & 2 & 2 & \pm & $\infty$ & $\approx$ & $\Xi$ & $\cong$ & $\pi$ & $\mathrm{d}$ & 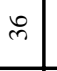 & $\cong$ & $\approx$ & in \\
\hline 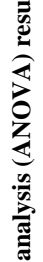 & 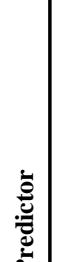 & & $\left|\begin{array}{l}\Xi \\
\Sigma \\
z\end{array}\right|$ & $\Xi$ & 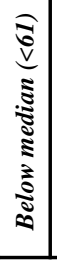 & 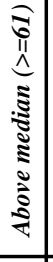 & $\begin{array}{l}\Xi \\
\Xi\end{array}$ & ฐँ & $\begin{array}{l}\text { 8ิ } \\
\text { II }\end{array}$ & $\pi$ & II & -1 & $\nu$ & $m$ & $\nabla$ & 0 & - & $\sim$ & $\infty$ & $z$ & $\stackrel{y}{2}$ & $i$ & 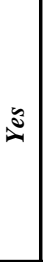 & 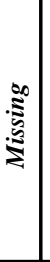 & $\underset{\text { III }}{\text { S }}$ & $\stackrel{\mathbb{I}}{\|}$ & 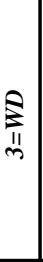 & $z$ \\
\hline 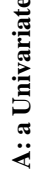 & & & 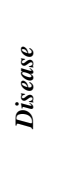 & & $\stackrel{8}{0}$ & & ڤ్ & & : & & & N & & & & $z$ & & & & 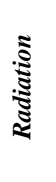 & & 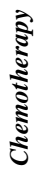 & & & 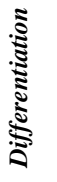 & & & 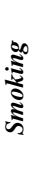 \\
\hline
\end{tabular}

Clin Cancer Res. Author manuscript; available in PMC 2013 September 01. 


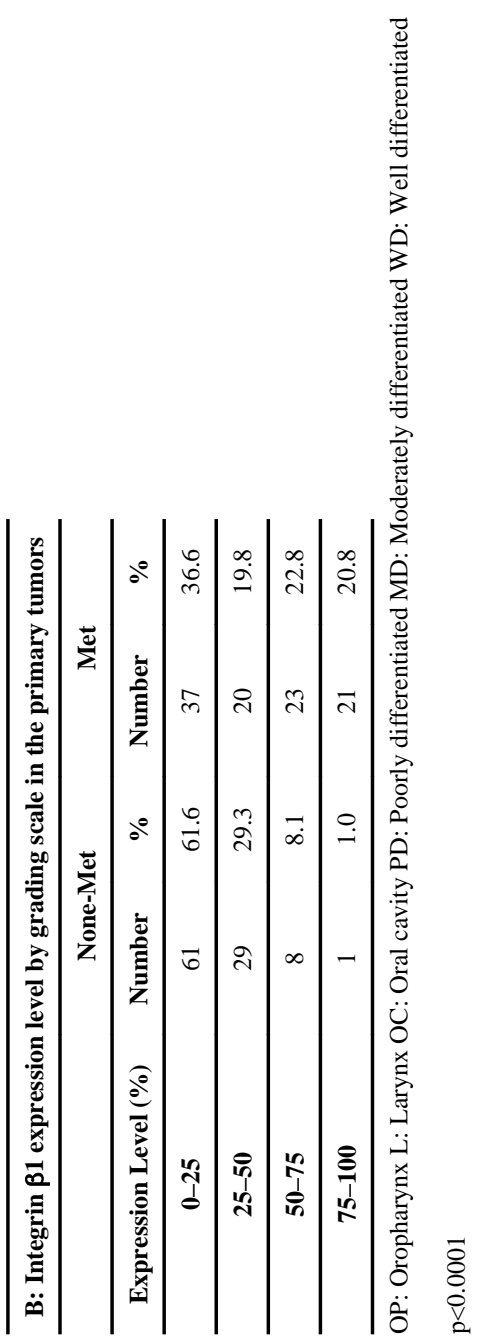




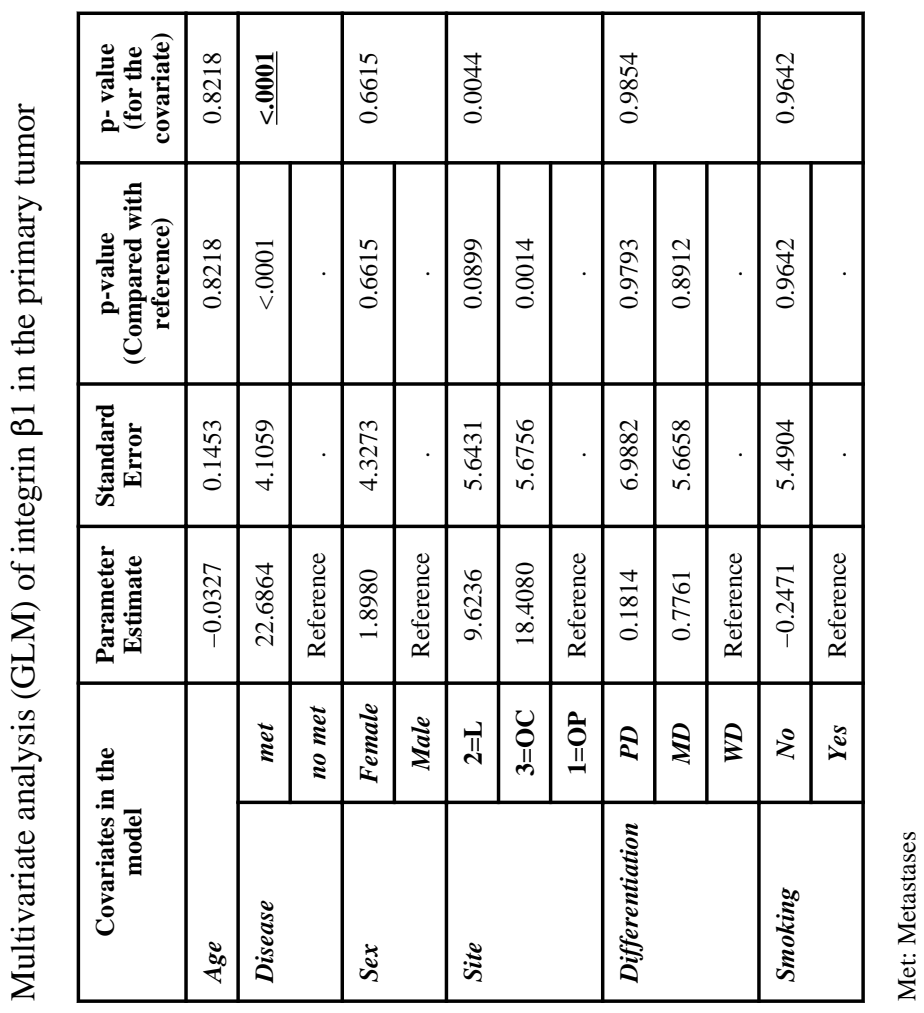

Clin Cancer Res. Author manuscript; available in PMC 2013 September 01. 